\title{
Effect of marital status, gender and job position in smoking behavior and cessation intent of staff members in a Central American public university
}

\author{
Lourdes Arce Espinoza and Julián Monge-Nájera \\ Biología Tropical, Universidad de Costa Rica, 2060 San José, Costa Rica; arcelourdes1@gmail.com, julianmonge@gmail.com
}

Received 15-VIII-2012 Corrected 21-IX-2012 Accepted 8-X-2012

\begin{abstract}
Smoking is one of the leading worldwide causes of cardiovascular disease and cancer development, and it not only affects the consumer but also those who are exposed to secondhand smoke. The economic cost of caring for the sick affects resources needed for education and prevention of addiction to cigarettes. This topic has been extensively studied in industrialized countries, but the information from Latin America is less available and seldom is based on inferential statistics applied to clear hypotheses, both central aspects in this article. To test several hypotheses on consumption and characteristics of patients we did an email survey to the entire staff of a state university in Costa Rica $(\mathrm{N}=2850)$ in 2012 . A $20 \%$ responded in a period of ten weeks and we applied a multiple regression to their answers. The results are statistically consistent with the hypothesis that being single, occupying high job positions and being male lead to increased consumption of tobacco and to an earlier start. To our knowledge, this is the first study using this methodology for the staff of any university in Central America.
\end{abstract}

\section{KEY WORDS}

Factors associated with smoking, Latin culture and smoking, use of tobacco by university staff, legal drugs, addiction.

\section{RESUMEN}

El fumado es una de las primeras causas a nivel mundial de enfermedades cardiovasculares y desarrollo de cáncer; no solo afecta al consumidor, sino a los que se encuentran expuestos al humo de segunda mano. El costo económico de atender a los enfermos no permite derivar recursos adecuados a la educación y prevención de la adicción al cigarrillo. El tema ha sido ampliamente estudiado en los países industrializados, pero la información de América Latina es menor y rara vez está basada en análisis de hipótesis con estadística inferencial, aspectos centrales considerados en este artículo. Para probar varias hipótesis sobre consumo y características de pacientes, hicimos en 2012 una encuesta vía correo electrónico a toda la población de una universidad estatal costarricense (2 850 funcionarios). Un $20 \%$ la respondió en un periodo de 10 semanas y con esa muestra aplicamos una regresión múltiple. Los resultados son estadísticamente coherentes con las hipótesis de que ser soltero, ocupar altos puestos y ser de sexo masculino llevan a un mayor consumo de tabaco y a iniciarse más tempranamente. Hasta donde sabemos, este es el primer estudio con esta metodología sobre fumado entre el personal de una universidad centroamericana.

\section{PALABRAS CLAVE}

Factores asociados con el tabaquismo, cultura latina y tabaquismo, uso de tabaco entre personal universitario, drogas legales, adicción.
Cigarette smoking is responsible for 5000000 deaths a year, causing premature death from cardiovascular diseases and cancer (Lutz-Ramírez \& Heibron, 2010). It affects the environment and consumes most of the health care resources destined for the consequences of its use (De Micheli \& Formigoni, 2004). Unfortunately, smoking is one of the most difficult addictions to overcome, and since it is a legal drug that produces an income for the stated, its control is particularly difficult (Lutz-Ramírez \& Heibron, 2010). In the world, a million young patients start smoking cigarettes annually and normally continue smoking for more than two decades (Price et al., 2003).

Smoking is also a moral problem because it not only the direct consumers, but also those exposed to "second hand smoking" in the same magnitude as if they had acquired the habit of smoking (Malone et al., 2000; Piko, 2002; Mathers et al., 2006). Furthermore, tobacco consumption is linked to the initiation and use of other drugs, especially the relationship between the consumption of tobacco and alcohol; there are also claims that it is the 
"trigger factor for consumption of both legal and illegal drugs" (De Micheli \& Formigoni, 2004).

Smoking explained nearly half the difference in coronary heart disease between women and men: men's mortality is five times higher and much of this difference is explained by smoking alone (Jousilahti et al., 1999). Often women are at a disadvantage, among lung cancer patients, even though men start smoking earlier, inhaled more deeply and consume more cigarettes per day, women had highest susceptibility to tobacco carcinogens (Zang \& Wynder, 1996). Even worse, later studies found that women react less and for shorter times to nicotine replacement therapies (Cepeda-Benito et al., 2004).

In the Central American country of Costa Rica, the mean age for the earliest use of tobacco went from 16 years in 1994, to 10 years in 2002 (Bejarano, 2005). Like in other countries, in Costa Rica it was found that in social groups where at least one members is an active smoker, the risk of occurrence and onset of smoking in other members of the same group increase (Bejarano, 2005). Nearly half a million patients smoke in the country and the smokers are mainly men but there has been an increase in smoking among women in the early 21st century (University of Costa Rica, 2006). The mean daily cigarette consumption in the country is 13 cigarettes for men and ten for women (Lutz-Ramírez \& Heibron, 2010). Advertising in the media is known to significantly increase consumption and in Costa Rica, the province of San Jose has the highest concentration of smokers and media presence (IAFA, 2010), albeit there are no studies that correct this result for population size (San José has a high concentration of population). The previous introduction summarizes the information available about smoking in Costa Rica, and to our knowledge, there are no studies that apply inferential statistics to test scientifically valid hypotheses about factors associated with smoking, and no studies about smoking among the staff of any Central American university. This is, then, the first study to focus on both aspects of the complex problem of smoking for this part of the world.

\section{METHODOLOGY}

We used the questionnaire Diagnóstico y nivel de dependencia del cigarrillo (Diagnosis and level of dependence on cigarettes) (IAFA, 2011) that consists of 13 items, divided into personal data, employment information, age of onset and active consumption of cigarettes. Our hypotheses were that being single, occupying high job positions and being male lead to increased consumption of tobacco and to an earlier start, as well as to a reduced interest in obtaining help to quit smoking.

\section{Procedure}

We sent a digital questionnaire, processed with a the software Checkbox Survey (checkbox.com) via the institutional electronic mail, to all staff members in a Costa Rican public university. The e-mail message linked to the software, requesting that it should be completed by both smokers and nonsmokers. The questionnaire was available for $2 \frac{1}{2}$ months and we sent weekly reminders until the period expired. We did statistical tests with the online program VassarStats (vassarstats.net).

\section{Sample}

The questionnaire was sent to the entire population of the university, about 2850 employees; 582 replies were received, a $20.46 \%$ of the total population, and the statistical tests were applied to all replies received.

\section{Ethics}

We followed all pertinent ethical guidelines described by Emanuel et al. (2000). Our study provides original and rigorously collected scientific information on a previously unknown subject; the results can be used to improve health care in the studied institution and similar environ $\neg$ ments; we only recorded data from staff members who were properly in $\neg$ formed about the study and accepted to participate; and no individual identities are presented or can be identified in this sample. Furthermore, no medical treatment was applied to any patients whatsoever.

\section{RESULTS}

There was no effect of position, division where they work and years with the institution, on the number of cigarettes smoked per day (for these and following results, the correlation and regression values appear in Appendix 1). However, marital status, sex and studies were commonly associated with smoking frequency. Bachelors smoke more than married patients, respondents with higher studies smoke more and men consume more cigarettes per day than women (Appendix 1).

The age at which they started smoking was not correlated with the number of years they have been working for the institution or with the number of cigarettes smoked each day (Appendix 1). On the other hand, marital status and sex were associated with onset age. Patients in higher job positions started earlier, and this is reflected in the "division" variable because academic and support 
divisions have, on the average, different educational levels in their staffs. Similarly, respondents with higher studies, who tend to ocuppy higher positions, started earlier. Men also started earlier than women (Appendix 1, available in the online version of the journal).

The time that the respondents had been without smoking was not correlated with the division where they work, years with the institution or number of cigarettes smoked per day (Appendix 1). The marital status and sex are associated, though. Men, and respondents with more advanced education (a correlate of the position they hold at the university) had been less time without smoking at the time of filling out the questionary (Appendix 1).

None of the variables we measured (position, division, years with institution, sex, level of studies, marital status and number of cigarettes smoked per day) was correlated with expressing a desire to receive assistance to stop smoking (Appendix 1).

\section{DISCUSSION}

\section{Smoking frequency}

A general finding in studies done in Western countries is that men smoke more frequently than women (Konrad et al., 1992) and we obtained the same result in our study. We also found that bachelors smoke more than married patients, also in agreement with previous findings which show that among external factors, the pressure and support of an spouse is significant to reduce smoking (Kabat \& Wynder, 1987). In general, married patients or patients who "feel loved" because they are in some kind of domestic partnership tend to reduce the practice of behaviors that are harmful to their health (Chacón \& Grau,1997; Novoa et al., 2004). Individuals whose work has greater time demands, or demands higher levels of concentration and extra work -for example those in top management jobssuffer higher stress levels and are more likely to smoke; in their case, smoking is used as a tool for psychosocial coping with stress. Patients who occupy high positions within an organization normally must have a high academic level and there is more competition for occupying those positions, generating more stress and thereby increase the consumption of tobacco, and when consumption started in adolescence or even childhood, tobacco is likely to remain as a mental stimulant for smokers (Joffre-Velázquez et al., 2007; Pinillos et al. , 2005).

The imminence of a stressful situation leads to increased consumption before and after the situation, particularly in patients with low skills to handle stressful situations, who often use smoking as an "emotional support" and painkiller (Wood et al., 2010). We found that patients with higher studies smoke more, as usual in Latin cultures, where smoking is perceived as an indicator of higher socioeconomic status, contrary to what was found in other countries such as the USA (Polleta et al., 2010). Even within the subgroup of education and health professionals, who are quite aware of the effects of smoking on health, there is an important proportion of smokers (Joffre-Velázquez et al., 2007; Pinillos et al., 2005). Considering that our population is from an institution of higher education, we conclude that our results fully agree with previous findings.

\section{Age at which patients start smoking}

As in the vast majority of studies related to global consumption of tobacco, we found that men tend to get into the habit of smoking earlier than women; this could be explained by peer pressure, general social exposure and the greater permissiveness that boys enjoy in their home environment when compared to girls; furthermore, advertising is attractive to this population (Joffre-Velázquez et al., 2007; Pinillos et al. ,2005) and in Costa Rica, where there is an oligopoly of tobacco companies, the advertisement of cigarettes was not limited in any way for more than a century (Monge, 2012).

\section{Time since the most recent episode of smoking}

The length of time that a smoker can resist without smoking is variable. Internal factors, and peer and spouse pressure and support are significant in this respect (Kabat \& Wynder, 1987). We found that men in general, and patients who occupy higher job positions in particular, waited less time to start the next cigarette after one was consumed, also in full agreement with the literature.

\section{Interest in receiving help to stop smoking}

A series of studies have led to a preliminary list of factors that favor the cessation of smoking; they refer to external characteristics (such as ethnic group and marital status) and to internal characteristics (still poorly known and related with hard to define traits such as "self steem" and "will power"). Ethnic groups with higher income have better education and are more likely to stop smoking (Khuder et al., 1999; Dube et al., 2009). Divorced and separated patients quit less because they do not have the support of an spouse; in fact, the spouse is twice as important as a friend or even a sibling in the decision to quit smoking (Christakis \& Fowler, 2008; Dollar et al., 2009; Dube et al., 2009). Finally, the smoking history of a person is highly significant. Those who start later in life are more likely to 
quit (Kabat \& Wynder, 1987; Khuder et al., 1999; Dube et al., 2009).

In our case, we found no effect of job position, years with institution, sex, level of studies finished or marital status on a desire to receive help for quitting, despite the fact that, on the basis of findings reported in the literature, we expected marital status to affect this parameter; and we similarly expected that smokers who started later in life would be more likely to show interest in quitting. We think that the reason for our result is that so few smokers wanted to quit that the statistical procedure could not find a pattern. Another possibility is that only internal factors, which we did not measure, are important in this particular population.

In conclusion, we found that the studied population is similar to other Latin populations studied previously, and the only exception referred to cessation and can be explained by the small size of the group interested in quitting. For future studies we recommend separation of two correlated factors that were impossible to distinguish in our study, as well as in practically all previous studies: educational level and economic status of patients. This will be difficult to do because normally patients with a higher educational level also have a higher economic status, but a deeper understanding of the phenomenom requires that distintion, and the current increase in unemployment among highly educated patients is producing such a population.

\section{REFERENCES}

Bejarano, J. (2005). El consumo de tabaco en jóvenes costarricenses escolarizados. Revista Costarricense de Psicología 36-37 (1), 11-21.

Cepeda-Benito, A., Reynoso, J.T. \& Erath, S. (2004). Meta-Analysis of the Efficacy of Nicotine Replacement Therapy for Smoking Cessation: Differences Between Men and Women. Journal of Consulting and Clinical Psychology 72 (4), 712-722. doi: 10.1037/0022-006X.72.4.712.

Chacón, M. \& Grau, J. (1997). Síndrome de estrés asistencial en enfermeros que brindan atención a pacientes oncológicos. Revista Cubana de Oncología 13 (2), 118-125.

Christakis, N.A.\& Fowler, J.H. (2008). The Collective Dynamics of Smoking in a Large Social Network. The New England Journal of Medicine 358, 2249-2258.

De Micheli, D. \& Formigoni, O.S. (2004). Drug use by Brazilian students: associations with family, psychosocial, health, demographic and behavioral characteristics. Addiction 99 (5), 570-578.

Dollar, K.M., Homish, G.G., Kozlowski, L.T. \&. Leonard, K.E. (2009). Spousal and Alcohol-Related Predictors of Smoking
Cessation: A Longitudinal Study in a Community Sample of Married Couples. American Journal of Public Health 99 (2), 231-233.

Dube, S.R., Asman, K., Malarcher, A. \& Carabollo, R. (2009). Cigarette smoking among adults and trends in smoking cessation - United States, 2008. Morbidity and Mortality Weekly Report 58 (44), 1227-1232.

IAFA. (2010). Distribución geográfica del consumo de drogas en Costa Rica, 2006. Instituto sobre Alcoholismo y Farmacodependencia: San José, Costa Rica.

IAFA. (2011). Diagnosis and level of dependence on cigarettes. Instituto sobre Alcoholismo y Farmacodependencia: San José, Costa Rica.

Joffre- Velásquez, V.M., García-Maldonado, G., Barrientos-Gómez, M. \& Vásquez-Nava, F. (2007). Consumo de tabaco en estudiantes de preparatoria de Tamaulipas, resultados preliminares. Revista Médica del Hospital General de México 70 (4), 175-179.

Jousilahti, P., Vartiainen, E., Tuomilehto, J. \& Puska, P. (1999).Sex, age, cardiovascular risk factors, and coronary heart disease: a prospective follow-up study of 14786 middle-aged men and women in Finland. Circulation 99 (9),1165-72.

Kabat, G.C. \&Wynder, E.L. (1987). Determinants of quitting smoking. American Journal of Public Health 77 (10), 1301-1305.

Khuder, S.A, Dayal, H.H \& Mutgi A.B. (1999). Age at smoking onset and its effect on smoking cessation. Addictive Behaviors 24 (5), 673-677.

Lutz-Ramírez, M. \& Heibron, E. (2010). Costo-efectividad del uso de la Vareniclina versus las alternativas existentes para la cesación del fumado usando el modelo BENESCO en la población adulta costarricense. Acta Médica Costarricense 52 (4), 211-220.

Malone, E.R., Boyd, E. \& Bero, A.L. (2000). Science in the News: Journalists Constructions of Passive smoking as a social problem. Social Studies of Science 30 (5), 713-735.

Mathers, M., Toumbourou, J.W., Catalano, R.F., Williams, J. \& Patton, G.C. (2006). Consequences of youth tobacco use: a review of prospective behavioural studies. Addiction 101(7), 948-958.

Monge, M.C. (2012) Economía del tabaco. Acta Médica Costarricense 54 (1), 8-14

Novoa, G.M., Nieto, D.C., Forero, A.C., Caycedo, C., Palma, M. Montealegre, M., Bayona, M. M, Sánchez, D.C. ( 2004). Relación entre perfil psicológico, calidad de vida y estrés asistencial en personal de enfermería. Revista de Psicología Pontificia Universidad Javeriana 4 (1), 63-75.

Piko, B. (2002). Does knowledge count? Attitudes toward smoking among medical, nursing, and pharmacy students in Hungary. Journal of Community Health 27 (4), 269-276.

Pinillos, L., Quesquén, M., Bautista, F. \& Poquimona, E. (2005). Tabaquismo: un problema de Salud Pública en el Perú. Revista Peruana de Medicina Experimental y Salud Pública 22 (1), 64-69. 
Polleta, F.A., Lopez-Camelo, J.S., Gili, J.A., Montalvo, G., Castilla, E.E. \& Red de Estudio Colaborativo Latinoamericanos de Malformaciones Congénitas. (2010). Consumo y exposición al humo de tabaco en mujeres embarazadas en Ecuador. Revista Panamericana de Salud Pública 27 (1), 56-65.

Price, J., Yingling, F., Dake, J. \& Telljohann, S. (2003). Adolescent smoking cessation services of School - based Health Centers. Health, Education \& Behavior 30 (2), 196-208.
Wood, M.C., Cano-Vindel , A. Iruarrizaga, I., Dongil, E. \& Martín, S.J. (2010). Relaciones entre estrés, tabaco y trastornos de pánico. Ansiedad y Estrés 16 (2-3), 309-325.

Zang, E.A. \& Wynder, E.L. (1996). Differences in Lung Cancer Risk Between Men and Women: Examination of the Evidence. Journal of the National Cancer Institute 88 (3-4), 183-192.

NOTE

Appendix 1 is available in the online version of this journal: http://investiga.uned.ac.cr/revistas/index.php/cuadernos 
